BIBLIOTIKA : Jurnal Kajian Perpustakaan dan Informasi

Volume 2 Nomor 2, 2018

Journal homepage $:$ http://journal2.um.ac.id/index.php/bibliotika

\title{
PENGGUNAAN APLIKASI TURNITIN SEBAGAI SARANA CEK PLAGIARISME DALAM LAYANAN PERPUSTAKAAN UNIVERSITAS UKRIDA
}

\author{
Steven Yehezkiel Sinaga* \\ Universitas Kristen Krida Wacana
}

\begin{tabular}{|c|c|}
\hline $\begin{array}{l}\text { A R T I C L E } \\
\text { I N F O }\end{array}$ & A B S T R A C T \\
\hline $\begin{array}{l}\text { Article history: } \\
\text { Received: } 23 \text { Nov } 2018 \\
\text { Accepted: } 28 \text { Feb } 2019 \\
\text { Published: } \\
\text { Keyword: } \\
\text { Plagiarisme, Turnitin, } \\
\text { Karya Tulis }\end{array}$ & $\begin{array}{l}\text { Dengan banyaknya kasus plagiarisme yang terjadi dalam kalangan } \\
\text { akademis, terutama kalangan mahasiswa, membuat perpustakaan } \\
\text { UKRIDA ingin memberikan layanan untuk membantu mahasiswa } \\
\text { mengidentifikasi kesalahan apa saja yang terjadi dalam penulisan } \\
\text { karya tulis masing-masing dengan menerapkan aplikasi Turnitin } \\
\text { sebagai media pemeriksaan plagiarisme. Penelitian ini bertujuan } \\
\text { untuk menunjukkan bagaimana UKRIDA memberikan layanan } \\
\text { cek plagiarisme via turnitin terhadap karya tulis mahasiswa } \\
\text { lingkungan kampus tersebut. Dalam hasil penelitian dapat } \\
\text { disampaikan bahwa penggunaan aplikasi Turnitin dalam layanan } \\
\text { perpustakaan UKRIDA dapat membantu dalam mengetahui } \\
\text { indikasi plagiarisme dalam karya tulis mahasiswa yang disubmit, } \\
\text { walau masih adanya ketidakpahaman dalam menganalisis indikasi } \\
\text { hasil akhir plagiarisme dalam karya tulis masing-masing. } \\
\text { With the many cases of plagiarism that occur in academics, } \\
\text { especially students, making the UKRIDA library want to provide } \\
\text { services to help students identify any mistakes that occur in the } \\
\text { writing of their individual works by applying the Turnitin } \\
\text { application as a media for plagiarism examination. This study } \\
\text { aims to show how UKRIDA provides plagiarism check services } \\
\text { via turnitin to the student writings of the campus environment. } \\
\text { In the research results, it can be delivered that use of Turnitin } \\
\text { application in UKRIDA library services can help in identifying } \\
\text { indications of plagiarism in student papers submitted, although } \\
\text { there is still a lack of understanding in analyzing the plagiarism } \\
\text { final results in their individual papers. }\end{array}$ \\
\hline
\end{tabular}

\footnotetext{
* Corresponding author.

E-mail addresses: steven.sinaga@ukrida.ac.id (Steven Yehezkiel Sinaga)
}

ISSN : 2579-3802 (Online) - BIBLIOTIKA : Jurnal Kajian Perpustakaan dan Informasi is licensed under Creative Commons Attribution-ShareAlike 4.0 International License (http://creativecommons.org/licenses/BY/4.0/). 
Plagiarisme/plagiat merupakan sebuah tindakan yang tidak mencerminkan sikap seorang akademisi, dimana tindakan ini dapat dilihat dari tindakan penjiplakan atau meniru sebuah sumber penulisan tanpa melakukan perubahan dan mengakui karya tersebut sebagai karya sendiri. Sekarang ini, isu plagiarism masih menjadi isu yang hangat dibicarakan di semua lingkungan akademisi, terutama kalangan mahasiswa dan dosen. Berbagai cara untuk melakukan sosialisasi pencegahan plagiarise sudah dilakukan oleh pihak akademik, terutama perpustakaan untuk mengurangi kebiasaan plagiarism pada diri mahasiswa, namun tetap saja terjadi, baik sengaja maupun tidak sengaja.

Plagiarisme sendiri didefinisikan oleh The Oxford Advanced Learner's Dictionary (2001) sebagai 'sebuah tindakan yang mengambil ide orang lain dan menggunakannya sebagai milik sendiri'. Plagiarisme juga dibahas dalam Peraturan Menteri Pendidikan RI nomor 17 tahun 2010 dengan bunyi demikian, "Plagiat adalah perbuatan sengaja atau tidak sengaja dalam memperoleh atau mencoba memperoleh kredit atau nilai untuk sebuah karya ilmiah, dengan mengutip sebagian atau seluruh karya dan atau karya ilmiah pihak lain yang diakui sebagai karya ilmiahnya, tanpa menyatakan sumber secara tepat dan memadai", atau bisa merujuk pengertiannya menurut Kamus Besar Bahasa Indonesia, yaitu "Plagiat adalah pengambilan karangan (pendapat dan sebagainya) orang lain dan menjadikannya seolah-olah karangan (pendapat) sendiri”. Dan, menurut Retiz dalam Online Dictionary for Library and Information Science (diakses pada 4 September 2018), plagiarime dipahami sebagai "tindakan meniru atau melakukan imitasi yang nyaris sama dengan karya orang lain tanpa meminta izin dan memiliki kesengajaan menjadikan hasil karya tersebut sebagai milik pribadi”. Jadi, berdasarkan definisi berbagai sumber di atas secara keseluruhan, plagiarisme adalah tindakan yang tidak terpuji dan harus dihindari oleh penulis maupun akademisi.

\section{METODE}

Metode penelitian yang digunakan adalah kualitatif dengan pndekatan studi kasus pada pelaksanaan penggunaan aplikasi Turnitin di penelitian sebelumnya untuk dapat melakukan perbandingan dalam layanan perpustakaan UKRIDA Kampus 1 serta melakukan observasi langsung terhadap penggunaan aplikasi Turnitin (dalam hal ini, peneliti merupakan staff layanan referensi dan informasi perpustakaan UKRIDA dan mendapat akses untuk penggunaan aplikasi). Metode yang digunakan adalah menerima permohonan pengecekan plagiarisme dan melakukan respon terhadap kebutuhan mahasiswa yang membutuhkan. Jangka waktu pengambilan data adalah selama bulan April hingga bulan Oktober 2018, dengan mengambil sampel sejumlah 20 hasil pengecekan dari 110 entri data yang ada dalam database Turnitin UKRIDA.

\section{HASIL PENELITIAN}

\section{Jenis Plagiarisme}

Secara umum, Harris (2002) menjelaskan bahwa plagiarism merupakan konsep yang simple, dimana seseorang menggunakan kata-kata, ide atau berbagai informasi dari sumber yang diketahui berdasarkan pengalaman dan pengetahuan, seorang penulis harus memberikan kredit kepada sumber yang disitasi. Tidak memberikan kredit terhadap materi pengetahuan yang digunakan sudah langsung dianggap plagiarism. Jika diringkas dari definisi yang sudah disebutkan sebelumnya, inti dari pemahaman plagiarisme adalah: sebuah sumber informasi tidak hanya berupa kata-kata saja, tetapi juga memiliki material yang lain, seperti foto, video, dan kode komputer; plagiarisme terkadang tidak disengaja, sehingga tidak dapat didefinisikan sebagai kesalahan yang disengaja untuk meng kreditkan sebuah sumber informasi, sebuah sumber mungkin sudah di kreditkan, namun dilakukan secara tidak benar. Sehingga sebuah indikasi plagiarism bisa terjadi walaupun sudah ada sitasi yang dicantumkan, hak cipta tidak relevan dengan plagiarisme, namun dalam pemahaman ini tidak membahas status legal dari sebuah informasi karena ada beberapa elemen yang tidak relevan dengan indikasi plagiarism (seperti hak cipta, domain publik, perizinan untuk penggunaan dan sebagainya). 
Namun, untuk kasus plagiarism sekarang ini, lebih disebutkan jenis plagiarism seperti plagiarisme yang sudah terencanakan (intentional plagiarism), plagiarisme yang tidak direncanakan (unintentional plagiarism), dan self-recycling:

\section{Plagiarisme yang terencanakan (intentional plagiarism)}

Jenis plagiarisme ini merupakan jenis yang sering dilakukan oleh akademisi sekarang dengan tindakan seperti melakukan kecurangan dengan melakukan copy and paste terhadap beberapa kalimat, paragraph atau bahkan keseluruhan sebuah karya tulis tanpa melakukan quoting atau sitasi sumber bahan tersebut. Hal ini sudah bukan rahasia umum lagi mengingat sudah banyak open-access journal yang tersebar dalam internet dan dengan pengembangan teknologi sekarang ini, akademisi bisa mengakses dan mengedit dimanapun mereka berada. Atau kalau ditinjau lagi, ada kasus dimana seorang pengajar tahu beberapa karya mahasiswanya adalah plagiat tetapi dibiarkan begitu saja.

\section{Plagiarisme yang tidak disengaja / tidak direncanakan (unintentional plagiarism)}

Untuk hal ini, yang biasa terjadi adalah kasus dimana sebuah sumber tidak disitasi dengan jelas, dimana pemahaman ini dapat dikaitkan dengan keterbatasan pengetahuan dalam penggunaan sumber informasi, salah paham dalam memahami aturan sitasi, kesalahan penulisan catatan, terlalu bergantung terhadap opini yang tidak memahami bagaimana melakukan sitasi, dan kecerobohan dalam menerapkan aturan sitasi.

\section{Self-Recycling}

Untuk kasus ini, lebih terfokus pada penggunaan ulang karya tulis yang sudah dibuat sebelumnya secara keseluruhan, atau digunakan lagi dalam sebuah tugas baru, atau secara ringkas, merupakan daur ulang karya tulis yang sudah dibuat sebelumnya.

\section{Mengapa Harus Menghindari Plagiarisme}

Sebelumnya, kita harus memahami lebih lanjut mengapa plagiarisme terjadi, dengan berbagai alasan seperti keterbatasan waktu untuk menyelesaikan sebuah karya ilmiah, rendahnya minat baca dan analisis terhadap berbagai sumber rujukan yang dimiliki, kurang pemahaman tentang bagaimana dan kapan harus melakukan sitasi/ kutipan, dan yang paling umum sebabnya adalah, tidak adanya reviewer atau alat untuk memeriksa indikasi plagiarisme yang ada dalam sebuah karya tulis.

Harris (2017) dalam Using Sources Effectively, mengatakan bahwa kasus plagiarisme yang sering terjadi adalah plagiarisme yang terencana (intentional plagiarism), dan menyatakan bahwa plagiarisme seperti ini harus dihindari karena: plagiarisme terencana hanya akan merusak citra karakter seseorang; ikutilah Golden Rule dimana aturan ini sudah diadvokasi oleh banyak penulis, dengan penyataan "Berbuat baiklah kepada sesama dengan bagaimana cara orang lain berbuat baik terhadap anda juga", yang dimaksudkan adalah dengan tidak melakukan plagiarisme, berarti seorang penulis mampu membuat sebuah hubungan social yang baik; pelaku plagiat yang direncanakan hanya menipu diri mereka sendiri, dimana dengan melakukan plagiat tersebut, dapat diketahui bagaimana kualitas pendidikan dan pola piker orang-orang tersebut.

\section{Bagaimana Perpustakaan Universitas UKRIDA menyikapi tentang plagiarisme}

Universitas UKRIDA, sebagaimana dengan halnya kampus-kampus lain, juga menggalakkan konsep anti plagiarisme dalam karya tulis sivitas akademik mereka, baik mahasiswa maupun dosen. Untuk mendukung hal ini, Perpustakaan Universitas Ukrida sudah mulai menjalankan layanan cek indikasi plagiarisme pada tahun 2018 dengan menggunakan aplikasi Turnitin dan layanan ini sudah dijalankan oleh staff perpustakaan Universitas Ukrida dengan sistem terima dan kirim via e-mail yang sudah di buat perpustakaan khusus untuk layanan ini.

\section{Pemahaman Tentang Aplikasi Turnitin}

Turnitin merupakan aplikasi penulisan formatif yang memiliki tujuan akademis untuk menjadi sebuah media deteksi plagiarisme yang dapat digunakan oleh tenaga pengajar dan siswa didik untuk mengurangi tingkat plagiarisme dan mempertahankan integritas akademis (sumber: 
turnitin.com, 2011). Sistem kerja turnitin adalah mencocokkan sebuah karya tulis dengan database yang dimiliki oleh instansi-instansi yang berlangganan aplikasi turnitin, dan tidak terlepas juga dari sumber database online lainnya.

Pada awalnya, aplikasi turnitin diciptakan oleh Dr. John Barrie yang berasal dari University of Berkeley, California dengan tujuan mempermudah identifikasi plagiat dalam karya tulis akademik dengan sistem identifying dan comparing. Kemudian, walaupun banyak aplikasi cek plagiarisme bermunculan, Turnitin mulai menjadi aplikasi yang popular dan walaupun mendapat berbagai kritik, Turnitin sudah dianggap berguna karena aplikasi ini juga menyertakan report atau laporan indikasi plagiat, yang berguna untuk mengetahui bagian mana saja yang harus diperbaiki.

Sebuah universitas dapat menerapkan peraturan sistem aplikasi turnitin dalam kebijakan mereka untuk meningkatkan atau bahkan bisa menurunkan efek langsung dari turnitin itu sendiri. Dalam hal ini, antisipasi plagiarisme dapat di laksanakan dengan konsep kebijakan sebagai berikut: integrating institutional policy (mengintegrasikan kebijakan institusional); practice and traditions of assessment design (praktek dan tradisi desain penilaian); instruction of information for students (melakukan instruksi informasi untuk murid); revealing (terbuka dalam memberikan hasil pemeriksaan deteksi plagiarisme); suitable ways of penalties (institusi menetapkan hukuman yang disesuaikan dengan peraturan tentang anti plagiarisme).

Namun, layaknya sebuah aplikasi pemograman lainnya, Turnitin juga memiliki kelebihan dan kekurangan dalam sistemnya sendiri, seperti yang disebutkan oleh Malka (2017), kelebihan dan kekurangan Turnitin dijabarkan masing-masing. Ada lima kelebihan Turnitin. Pertama, simpel: software ini sangat mudah digunakan dan waktu yang digunakan tidak lama untuk memahami sistem turnitin. Kedua, cepat: dapat menunjukkan hasil pemeriksaan dalam tempo waktu yang cepat walaupun bergantung dengan kondisi sistem utama turnitin dan didukung dengan proses upload yang cepat juga. Ketiga, kemudahan akses: merupakan aplikasi yang berbasis web, turnitin dapat diakses dari berbagai macam browser dan dapat memudahkan dalam proses submit dimanapun penggunanya berada. Keempat, penandaan dan penilaian tugas dengan sistem rubric: Turnitin memiliki mark-up tool yang digunakan untuk memperbaiki dan memberi nilai tugas dalam bentuk pdf atau doc dalam format online. Kelima, cakupan sumber yang luas: dalam deteksi, turnitin mencakup sumber referensi dokumen di internet dalam cakupan yang sangat luas.

Selain itu ada enam kekurangan Turnitin. Pertama, Pencocokan konten isi yang "Tidak cerdas":Turnitin tidak dapat mengenali formula matematis yang seharusnya tidak perlu di di perhitungkan dalam memeriksa sebuah konten. Kedua, memasukkan kalimat kutipan langsung atau kalimat yang di paraphrase sebagai indicator plagiarism. Ketiga, batas ukuran file yang bisa di upload hanya $10 \mathrm{MB}$ sehingga akan menyulitkan yang menggunakan elemen grafis yang biasanya berukuran besar. Keempat, Turnitin hanya bisa menerima format file pdf dan word, dan tidak bisa melakukan multiple submit sehingga harus melakukan penggabungan file dengan batasan size tertentu. Kelima, tampilan pengguna yang monoton sehingga tidak membuat pengguna menikmati aplikasi ini. Keenam, aplikasi ini dapat di akali dengan mengupload dokumen image atau gambar sehingga bisa ada kemungkinan memperoleh $0 \%$ indeks plagiarismenya. Meski demikian, turnitin tetap menjadi salah satu solusi alternatif untuk membantu akademisi mengetahui indikasi plagiarisme yang terdeteksi dalam karya ilmiah / penelitian masing-masing penulis.

\section{Penggunaan Aplikasi Turnitin oleh Perpustakaan UKRIDA}

Perpustakaan Ukrida sudah menjalankan layanan cek plagiarisme sejak April 2018, dimana perpustakaan Ukrida sudah melakukan sosialisasi terhadap sivitas dosen untuk memahami penggunaan aplikasi ini. Untuk dapat menggunakan layanan tersebut, sivitas Ukrida, baik mahasiswa ataupun dosen, bisa mengirimkan via e-mail ke e-mail yang sudah disiapkan perpustakaan Ukrida yang secara khusus sudah dibagi per jurusan (sejauh ini ada tiga e-mail untuk memudahkan proses pengecekan, dengan contoh sebagai berikut : E-mail 
libturnitin1@ukrida.ac.id dikhususkan untuk jurusan [...], e-mail libturnitin2@ukrida.ac.id dikhususkan untuk jurusan [..] dan email libturnitin3@ukrida.ac.id dikhususkan untuk jurusan magister manajemen).

Pada dasarnya, penggunaan aplikasi Turnitin di Perpustakaan Ukrida itu sendiri tidak jauh berbeda dengan bagaimana instansi lain menggunakan Turnitin, dimana melalui prosedur umum seperi melakukan log-in pada website Turnitin dan memilih class yang sudah dibuatkan oleh Kepala Perpustakaan Ukrida sebelumnya seperti ini :

Gambar 1: Tampilan Class yang sudah dibuat sebelumnya

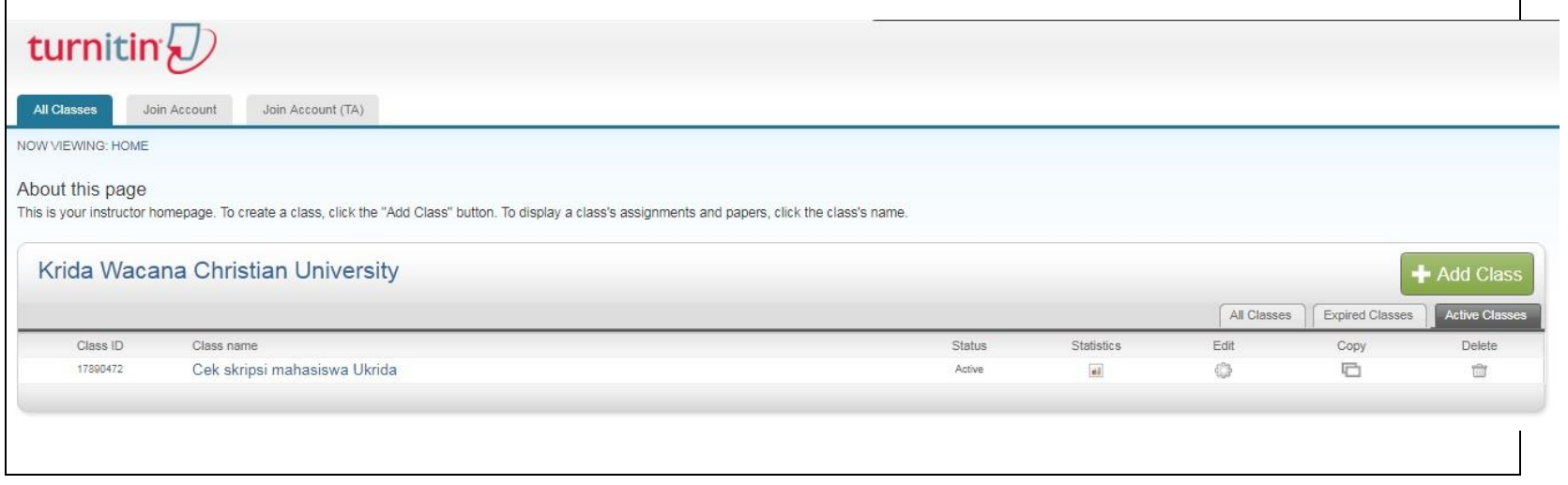

Dan setelahnya, pelaksana layanan masuk ke dalam assignment yang sudah dibuat juga sebelumnya :

Gambar 2: Tampilan Assigment pada Turnitin yang sudah dibuat dalam Class sebelumnya. Kemudian, pelaksana dapat melakukan pengecekan dengan melakukan submit karya tulis yang sudah diterima sebelumnya via e-mail dengan opsi Submit File seperti tampilan ini:

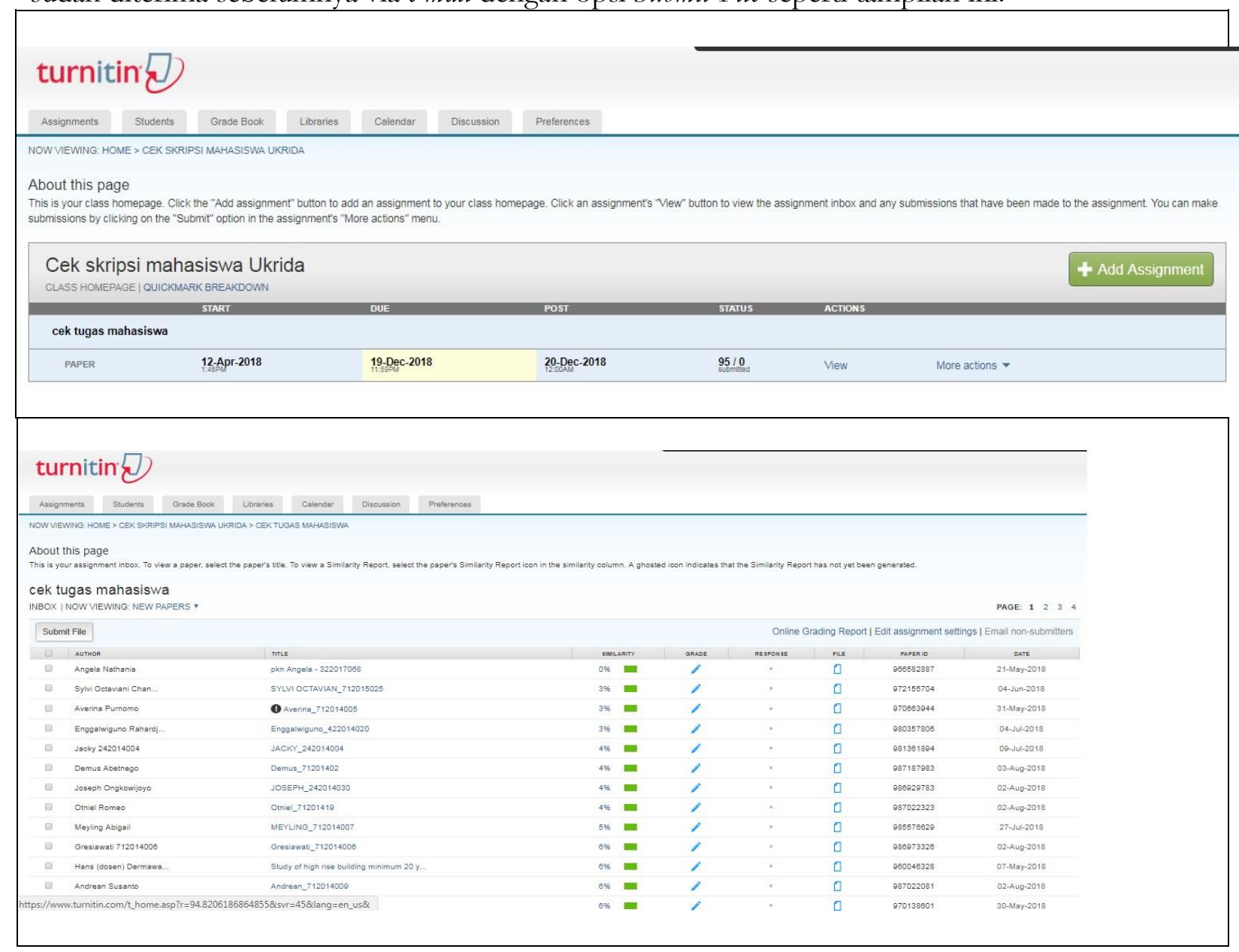


Gambar 3: Tampilan Submit File dengan hasil presentasi dari karya tulis yang sudah di cek sebelumnya

Dan pelaksana mengisikan form submit yang sudah muncul dengan urutan sebagai berikut: author dikategorikan Non-Enrolled Student; first name diisikan dengan Nama depan mahasiswa/dosen yang melakukan submit; last name diisikan dengan nama belakang mahasiswa/dosen, atau jika dalam kasus nama seseorang hanya terdiri dari satu nama saja (tanpa ada nama tengah dan belakang, dan untuk lingkungan Perpustakaan Ukrida, dicek lagi dengan database mahasiswa yang dimiliki dengan acuan nomor induk mahasiswa/NIM), submission title diisikan dengan format yang sudah ditentukan oleh Kepala Perpustakaan Ukrida, yaitu Nama (dalam format capital)_NIM Mahasiswa bersangkutan; untuk submit file, biasanya mengambil dari folder download yang menjadi default folder dari komputer layanan pemeriksaan plagiarisme perpustakaan Ukrida (walaupun ada opsi lain seperti Google Drive atau Dropbox), dan format nama file sendiri disesuaikan dengan kemudahan mencari dalam folder download (alternatifnya, pelaksana memiliki hak untuk melakukan rename terhadap dokumen yang akan di submit).

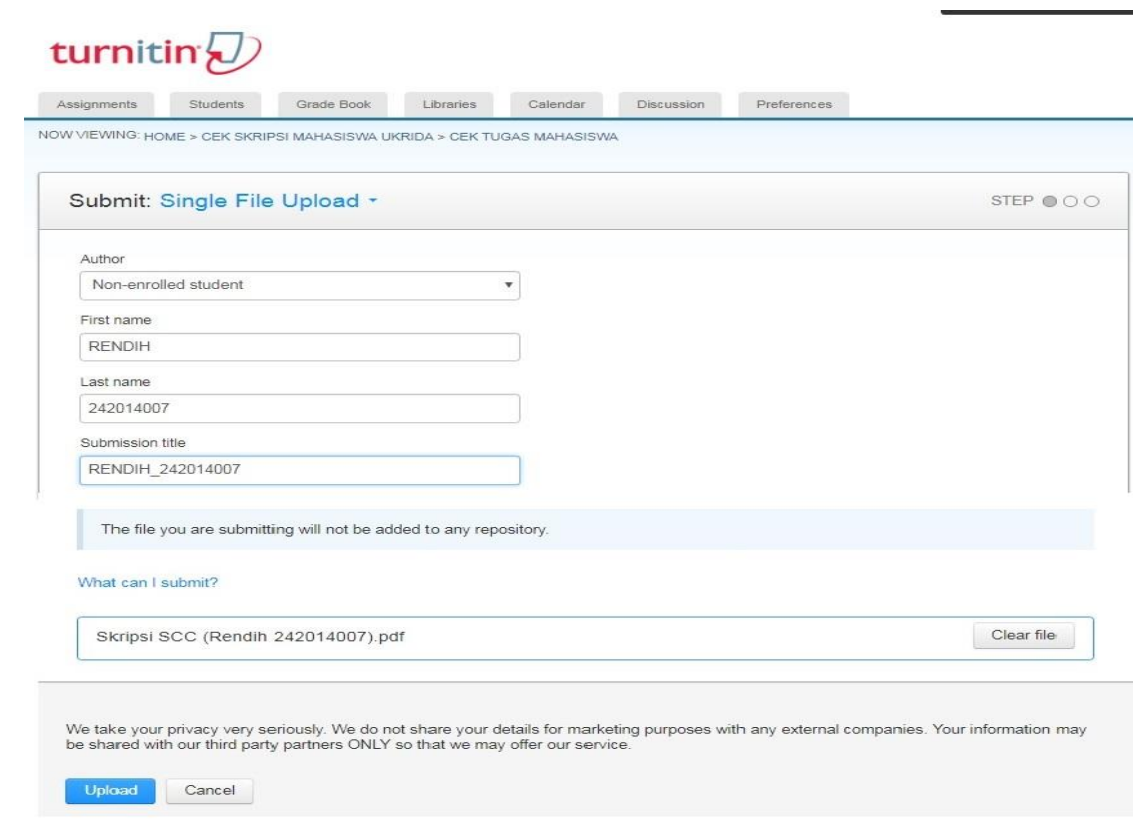

Gambar 4: Tampilan Submit yang sudah diisikan data dari yang melakukan permohonan layanan cek plagiarisme beserta upload dokumen

Setelah melakukan submit, biasanya pelaksana harus menunggu sekitar 5 - 20 menit (biasanya bisa dikarenakan faktor jaringan internet) dan juga disesuaikan dengan besarnya file yang di upload, dimana dalam pelaksanaan layanan, pelaksana pernah mendapatkan submit file dimana mahasiswa tersebut menyertakan bab-bab lainnya, sehingga hal tersebut bisa membuat proses pengecekan menjadi lama. Oleh karenanya, pihak Perpustakaan Ukrida sudah membuat kebijakan dimana sivitas sebaiknya submit bagian yang ingin di cek indikasi plagiarismenya saja, tanpa harus menyertakan hal lain seperti kover, kata pengantar, daftar isi, dan sebagainya.

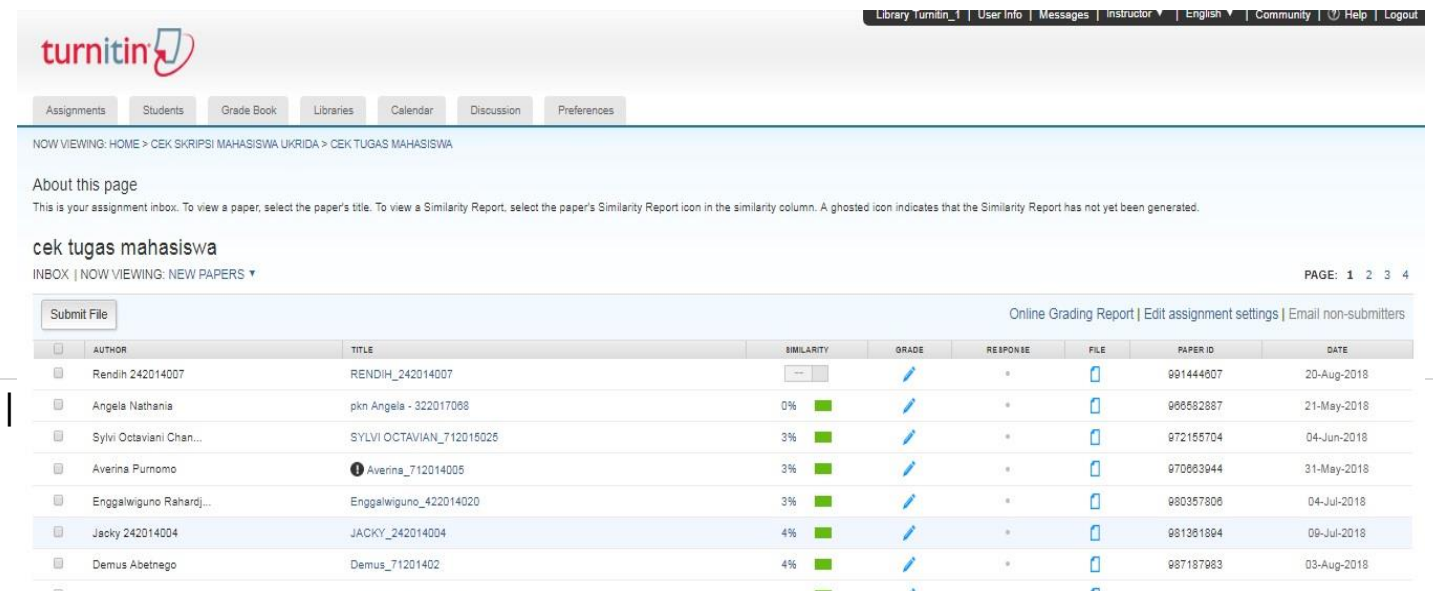


Gambar 5 : Tampilan dimana sedang terjadi proses pengecekan karya ilmiah yang sudah disubmit oleh pelaksana layanan

Nantinya, jika sudah selesai proses, presentase akan keluar seperti daftar yang sudah ditampilkan sebelumnya, dan untuk dapat mengecek indikasi plagiarisme secara lengkap, hanya perlu melakukan click pada link judul title sesuai dengan nama yang akan di cek tingkat plagiarismenya. Kemudian, hasilnya akan keluar di window browser baru seperti berikut:

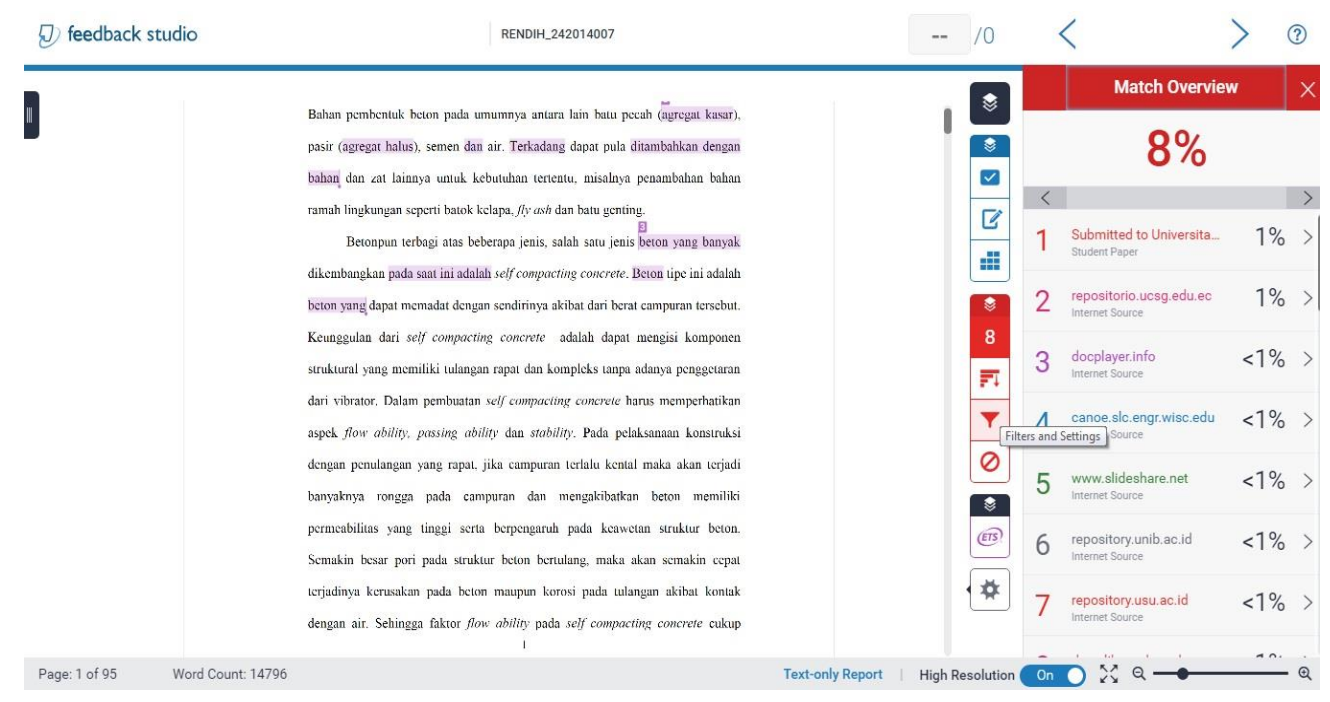

Gambar 6: Tampilan feedback studio dimana tercantum bighlight bagian yang dianggap merupakan indikator plagiarisme.

Setelah itu, hasil pemeriksaan akan di download dan akan dikirimkan kepada e-mail pengguna layanan penelusuran informasi. Jika pengguna belum memahami maksud dari indicator plagiarisme, akan diinformasikan untuk bertanya kepada Kepala Perpustakaan Ukrida melalui isi e-mail yang dikirimkan.

\section{PEMBAHASAN}

Kendala yang di hadapi dalam Penggunaan Turnitin dalam Pengecekan Plagiarisme dalam lingkup Perpustakaan Ukrida

Pelaksanaan Turnitin telah berjalan sekitar 9 bulan, namun tetap saja ada kendala yang dialami oleh staff pelayanan pengecekan plagiarisme dalam melaksanakan pekerjaannya, baik dari tenaga maupun sarana dan perspektif dari pengguna layanan tersebut yang mempengaruhi presentase plagiarisme.Terlebih dahulu, dalam sisi yang mempengaruhi presentasi plagiarisme, staff pelaksana menemukan hal-hal berikut dalam pelaksanaan layanan dari sisi pengguna sebagai berikut: minimnya pengetahuan tentang sintesis kata dalam mengutip dasar teori yang digunakan; 
kurangnya pemahaman tentang Parafrase kata dari sumber teks yang digunakan; penggunaan quote yang masih sama dengan referensi yang digunakan; masih adanya anggapan tindakan copy and paste tidak akan di ketahui oleh dosen; untuk kasus pemeriksaan skripsi, judul cover mempengaruhi presentasi plagiarisme dengan mendeteksi sumber dengan judul yang sama; user memiliki pendapat bahwa mereka juga diperbolehkan mendapat hak akses Turnitin untuk mempermudah mereka dalam memeriksa tingkat plagiarisme mereka. Sedangkan dari sisi aplikasi, sebagai berikut: mengambil acuan dari referensi yang sumbernya tidak diketahui legit / tidak jelas (open access); format konteks dalam bentuk gambar (JPEG); pengecekan dokumen dipengaruhi oleh besar dokumen dan banyaknya grafis dalam dokumen tersebut.

Dari penarikan persepsi seperti diatas berdasarkan observasi langsung dan interaksi dengan mahasiswa yang melakukan permohonan pengecekan plagiarisme, hampir dalam cakupan 25 sampel hasil pengecekan plagiarisme mengalami masalah yang sama, yaitu pada point nomor 1 - 4, dimana mereka mengambil dari sumber informasi tanpa mengutip dan mengubah susunan kalimat dan bersikeras mereka sudah melakukan parafrase dan mengubah susunan kata sesuai dengan bahasa mahasiswa masing-masing. Namun, disamping beberapa kendala diatas, user sudah memahami bagaimana penilaian dari aplikasi Turnitin itu sendiri serta sudah dapat mengadaptasi bagaimana mengurangi tingkat presentase plagiarisme dari dokumen user masingmasing.

\section{PENUTUP}

\section{Simpulan}

Dari penelitian diatas, dapat disimpulkan bahwa aplikasi Turnitin dapat dimanfaatkan sebagai aplikasi untuk membantu user dalam memahami tingkat plagiarisme yang terdeteksi dalam karya masing-masing. Namun, sebagai pengguna aplikasi, staff pelaksana harus memahami bahwa aplikasi ini masih memiliki beberapa kekurangan dalam mendeteksi sumber yang dihubungkan dengan beberapa bagian dari dokumen yang diteliti tingkat plagiarismenya, sehingga pelaksana harus teliti dalam menyampaikan gambaran presentase plagiarisme serta menjelaskan bagaimana user dapat mengurangi tingkat plagiarisme dari dokumen mereka. Hal ini berarti pelaksana dan juga dosen dari user juga membantu mereka memahami bagaimana melakukan parafrase dan sintesis kata dalam dokumen mereka, serta pengutipan teori sebagai landasan karya mereka.

\section{DAFTAR PUSTAKA}

Bensal, E. R., Miraflores, E. S., \& Tan, N. C. C. (2013). Plagiarism: Shall We Turn to Turnitin? Call-Ej, 14(2), 2-22.

Brabazon, T. (2015). Turnitin? Turnitoff: The deskilling of information literacy. Turkish Online Journal of Distance Education, 16(3), 13-32. https://doi.org/10.17718/tojde.55005

Dahl, S. (2007). The student perspective on using plagiarism detection software. Active Learning in Higher Education, 8(2), 173-191. https://doi.org/10.1177/1469787407074110

Harris, Robert A. (2017). Using Source Effectively. New York, NY: Routledge.

Halgamuge, M. N. (2017). The use and analysis of anti-plagiarism software: Turnitin tool for formative assessment and feedback. Computer Applications in Engineering Education, 25(6), 895909. https://doi.org/10.1002/cae.21842

Han, L., \& Goulding, A. (2003). Information and reference services in the digital library. Information Services and Use, 23(4), 251-262. https://doi.org/10.3233/ISU-2003-23406

Herqunanto. (2013). Plagiarisme, Runtuhnya Tembok Kejujuran Akademik. EJKI, 1(1), 1-3.

Ledwith, A., \& Rísquez, A. (2008). Using anti-plagiarism software to promote academic honesty in the context of peer reviewed assignments. Studies in Higher Education, 33(4), 371-384. https://doi.org/10.1080/03075070802211562

Li, J., \& Li, M. (2018). Turnitin and peer review in ESL academic writing classrooms. Language Learning \& Technology, 22(1), 27.

Orlando, J., Hanham, J., \& Ullman, J. (2018). Exploring intentional use of a technological proxy, 
Turnitin, to enhance student academic literacy practices. Australasian Journal of Educational Technology, 34(4), 44-56. https://doi.org/10.14742/ajet.3575

Prihantini, F. N., \& Indudewi, D. (2016). Kesadaran dan perilaku plagiarisme dikalangan mahasiswa: Studi pada mahasiswa fakultas Ekonomi jurusan Akuntansi Universitas Semarang. Jurnal Dinamika Sosial Budaya, 18, 68-75.

Service, P. D. (n.d.). A Very Quick Guide to Turnitin What is Turnitin? Creating a Turnitin assignment.

Suryana, E. (2016). Self Efficacy Dan Plagiarisme Di Perguruan Tinggi. | Tadrib, II(02), 1-24.

Walchuk, K. (2016). An examination of the efficacy of the plagiarism detection software program Turnitin.

Wibowo, A. (2011). Mencegah dan Menanggulangi Plagiarisme di Dunia Pendidikan. Jurnal Kesehatan Masyarakat Nasional, 6(5), 195-200. 